\title{
Analysis of Blood Donor Deferral in a Tertiary Care Hospital
}

\author{
F Parvin ${ }^{1}$, D A Biswas ${ }^{2}$, B Naznin ${ }^{3}$, T Afroz ${ }^{4}$, M Ali ${ }^{5}$, T F Dipta ${ }^{6}$
}

1 Dr. Farida Parvin Assistant Professor Dept. of Transfusion Medicine and Clinical Haematology BIRDEM General Hospital and Ibrahim Medical College, Dhaka

${ }^{2}$ Dr. Daanish Arefin Biswas Associate Professor Dept. of Transfusion Medicine Sir Salimullah Medical College and Mitford Hospital, Dhaka.

${ }^{3}$ Dr. Bepasha Naznin
Transfusion Specialist
Dept. of Transfusion Medicine
Asgar Ali Hospital, Dhaka
${ }^{4}$ Dr. Tamanna Afroz
Registrar
Dept. of Transfusion Medicine
Apollo Hospital, Dhaka
${ }^{5}$ Dr. Mohammad Ali
Junior Consultant
Dept. of Surgery, Sadar Hospital
B-Baria
${ }^{6}$ Prof. Tashmim Farhana Dipta
Professor and Head
Dept. of Transfusion Medicine and
Clinical Haematology
BIRDEM General Hospital and
Ibrahim Medical College, Dhaka
Correspondence
Dr. Farida Parvin
Assistant Professor,
Dept. of Transfusion Medicine and
Clinical Haematology,
BIRDEM General Hospital, Dhaka
E-mail: dr.farida1984@gmail

${ }^{3}$ Dr. Bepasha Naznin Transfusion Specialist Dept. of Transfusion Medicine Asgar Ali Hospital, Dhaka

${ }^{4}$ Dr. Tamanna Afroz Registrar Dept. of Transfusion Medicine ospital, Dhaka

Dr. Mohammad Al

Dept. of Surgery, Sadar Hospital

${ }^{6}$ Prof. Tashmim Farhana Dipta Dept. of Transfusion Medicine and Clinical Haematology BIRDEM General Hospital and

Correspondence

Dr. Farida Parvin

Assistant Professor,

edicine and BIRDEM General Hospital, Dhaka E-mail: dr.farida1984@gmail

\section{Abstract}

Introduction : Selection of proper donor according to stringent selection criteria is the prerequisite for safe blood transfusion practice. It is widely known that a large number of blood donors are deferred for different reasons.

Objective : The aim of present study is to evaluate the incidence and different reasons of blood donor deferral in atertiary care hospital.

Methodology : This retrospective cross-sectional study was carried out in Transfusion Medicine and Clinical Haematology Department of BIRDEM General Hospital, Dhaka, during the period from July 2016 to June 2017.The blood donor of either sex attending the mentioned department were selected purposively and categorized into four groups according to their age for this study. Donors were selected and deferred by medical officer according to national guideline. Deferred blood donors were recorded in register book and were analyzed retrospectively.

Results : In current study, 1152 blood donor (8.8\%) were deferred attending for allogeneic blood donation during the study period. Out of 13082 registered blood donor 11961 were male (91.43\%) and 1121 were female $(8.57 \%)$ and deferral rate was 2.37 times more in female. Majority of the deferred donors (55.38\%) were under the age of 40 where $26.82 \%$ were in between $40-49$ years and $17.8 \%$ were in the range of 50 years and above. Age range of highest deferred donors $(32.20 \%)$ was between 30-39 years. The number of temporary and permanent deferral were 836 $(72.57 \%)$ and $316(27.43 \%)$ respectively. Anaemia $(33.01 \%)$, underweight $(21.53 \%)$ and hypotension $(17.34 \%)$ were the most common reason of temporary deferral. Chronic uncontrolled hypertension $(42.4 \%)$, donors with medication $(16.77 \%)$ and asthma $(15.18 \%)$ was the most common cause of permanent deferral.

Conclusion : The deferral rate was low and most of the deferred donors were young adult. Temporary deferred donors were higher than permanent deferred donors. The most common reasons for temporary deferral were anemia, underweight and hypotension. Permanent deferral causes were chronic uncontrolled hypertension, donors on medication for various reason and asthma. Donors should be informed with a clear message on their deferral status. It is important to determine the rate and causes of donor deferral for the safety of blood transfusion and to guide the recruitment efforts for safe blood transfusion and to avoid the permanent loss of blood donors.

Key words : Blood donor, Anaemia, Temporary Deferral, Permanent Deferral.

DOI: https://doi.org/10.3329/nimcj.v10i2.45431

Northern International Medical College Journal Vol. 10 No. 2 January 2019, Page 373-376

\section{Introduction}

Blood transfusion is one of the common medical practice and also a life saving procedure that requiring sufficient supply of safe blood. For safe blood transfusion, many safety measures are commenced by the blood transfusion community where the most necessary is proper donor selection. ${ }^{1}$ Individual disqualified from donating blood are known as "deferred" donors.
The WHO Global Database indicated that $>92$ million blood donations are collected annually from 164 different countries around the world. Around 1.6 million units were discarded due to the presence of infections such as hepatitis $B$ and $\mathrm{C}$, HIV, herpes and syphilis. In addition, at least 13 million donors were deferred due to having the risk of infection that could be 
transmitted through blood, a preexisting medical disease or anemia. Due to this, blood donor selection is a cornerstone for blood transfusion safety, designed to safeguard the health of both donors and recipients. Blood donor eligibility is determined by medical interview, based on national guidelines for donor selection. ${ }^{2}$ A prospective donor may be deferred at any point during the collection and testing process either temporarily or permanently depending on the specific reason for disqualification. If a donor is to be deferred, his or her name is entered into a list of deferred donors maintained by the blood transfusion center, often known as the "deferral registry." If a deferred donor attempts to give blood before the end of the deferral period, the donor will not be accepted for donation. Once the reason for the deferral no longer exists and the temporary deferral period has lapsed, the donor may return to the blood transfusion center and be re-entered into the system, ${ }^{3}$ Deferred donor experience a troublesome feeling during donor selection and mostly leaves them with negative perception, about themselves as well as the blood donation process. Additionally these donors are less likely to come-back for future blood donation. ${ }^{4}$

\section{Materials and Methods}

The current retrospective record based study was carried out on 13082 blood donor attending to Transfusion Medicine and Clinical Haematology department, BIRDEM General Hospital, Dhaka from July 2016 to June 2017.The blood donor of either sex attending the mentioned department were selected purposively and categorized into four groups according to their age.

Preliminary donor selection was done by using donor questionnaire prepared following national guide line, brief physical examination of donors with regard to pulse, blood pressure and temperature and post donation screening along with hemoglobin estimation by hemoglobin meter were done. After completion of blood collection donor samples were tested for Hepatitis B (HBsAg), Hepatitis C virus(Anti HCV), Human Immunodeficiency Virus (HIV 1 \&2), Syphilis and Malaria. If any of the tests were positive then the blood was discarded and the donor was referred to respective department for further management.
Donors were selected and/or deferred by Medical officer according to national guideline. Deferred blood donors were recorded in Register book. All data from records were then analyzed as percentage and proportion. Data analysis was performed on SPSS for Windows Version 18.(IBM Corp, New York, USA).

\section{Results}

The result showed that out of 13082 registered blood donors attending for allogeneic blood donation during the study period, $1152(8.8 \%)$ were deferred donor and among total number of donor 11961 were male (91.43\%) and 1121 were female (8.57\%). Deferral rate among male $7.87 \%$ and among female $18.73 \%$ which was 2.37 times more in female. Majority of the donors were under the age of $40(55.38 \%), 26.82 \%$ were in between $40-49$ years and $17.8 \%$ were in the range of 50 years and above where most of the deferred donors were between 3039 years. Deferred blood donor were classified into temporary and permanent .The number of temporary and permanent deferral were $836(72.57 \%)$ and $316(27.43 \%)$ respectively. (Table 1)

Table I : Total donor, deferred donor by sex and type of donor

\begin{tabular}{lccc} 
Donor & Male & Female & Total \\
Number of donor & 11961 & 1121 & 13082 \\
Number of deferred donor & 942 & 210 & 1152 \\
Percentage deferred & $7.87 \%$ & $18.73 \%$ & $8.8 \%$ \\
Deferred donors by age and sex $(\mathbf{n = 1 1 5 2 )}$ & & \\
\hline Age (years) & Male & Female & Total \\
$18-29$ & 124 & 143 & $267(23.18 \%)$ \\
$30-39$ & 322 & 49 & $371(32.20 \%)$ \\
$40-49$ & 293 & 16 & $309(26.82 \%)$ \\
50 years and above & 203 & 2 & $205(17.8 \%)$ \\
Total & $942(81.77 \%)$ & $210(18.23 \%)$ & $1152(100 \%)$
\end{tabular}

Classification of Deferred donors

$\begin{array}{lcc}\text { Deferred donors type } & \text { Number } & \text { Percentage } \\ \text { Temporary deferral } & 836 & 72.57 \% \\ \text { Permanent deferral } & 316 & 27.43 \% \\ \text { Total } & \mathbf{1 1 5 2} & \mathbf{1 0 0 \%}\end{array}$

The main causes of temporary deferral were Anaemia 276(33.01\%), underweight180 (21.53\%) and hypotension145 (17.34\%) (Table II) 
Table II : Distribution of temporary deferral by age and sex $(n=836)$

\begin{tabular}{|c|c|c|c|c|c|c|c|c|c|c|c|c|}
\hline \multirow[t]{2}{*}{ Causes } & \multicolumn{2}{|c|}{$\begin{array}{c}18-29 \\
\text { yrs }\end{array}$} & \multicolumn{2}{|c|}{$30-39$ yrs } & \multicolumn{2}{|c|}{$40-49$ yrs } & \multicolumn{2}{|c|}{$50-60$ yrs } & \multicolumn{2}{|c|}{ Total } & \multirow[t]{2}{*}{$\begin{array}{l}\text { Grand } \\
\text { Total }\end{array}$} & \multirow[t]{2}{*}{$\begin{array}{c}\text { Percentage } \\
(\%)\end{array}$} \\
\hline & $\mathbf{M}$ & $\mathbf{F}$ & $\mathbf{M}$ & $\mathbf{F}$ & $\mathbf{M}$ & $\mathbf{F}$ & $\mathbf{M}$ & $\mathbf{F}$ & $M$ & $\mathbf{F}$ & & \\
\hline Anaemia & 21 & 69 & 68 & 19 & 53 & 7 & 38 & 1 & $\begin{array}{c}180 \\
(28.16 \%)\end{array}$ & $\begin{array}{c}96 \\
(48.73 \%)\end{array}$ & 276 & $33.01 \%$ \\
\hline Underweight & 15 & 35 & 57 & 13 & 25 & 3 & 32 & - & $\begin{array}{c}129 \\
(20.18 \%)\end{array}$ & $\begin{array}{c}51 \\
(25.88 \%)\end{array}$ & 180 & $21.53 \%$ \\
\hline Hypotension & 9 & 14 & 54 & 8 & 23 & 2 & 35 & - & $\begin{array}{c}121 \\
(18.93 \%)\end{array}$ & $\begin{array}{c}24 \\
(12.18 \%)\end{array}$ & 145 & $17.34 \%$ \\
\hline $\begin{array}{c}\text { Feverdue to } \\
\text { bacterial,viral, } \\
\text { fungal } \\
\text { infections }\end{array}$ & 7 & 3 & 23 & 1 & 28 & - & 17 & - & $\begin{array}{c}75 \\
(11.73 \%)\end{array}$ & $\begin{array}{c}4 \\
(2.03 \%)\end{array}$ & 79 & $9.45 \%$ \\
\hline Typhoid fever & 3 & 2 & 13 & - & 7 & 1 & 9 & - & $32(5.05 \%)$ & $3(1.52 \%)$ & 35 & $4.18 \%$ \\
\hline $\mathrm{H} / \mathrm{O}$ icterus & 2 & 3 & 19 & - & 18 & - & 2 & - & $41(6.41 \%)$ & $\begin{array}{c}3 \\
(1.52 \%)\end{array}$ & 44 & $5.26 \%$ \\
\hline Tatto & 3 & - & 6 & - & 3 & - & - & - & $12(1.87 \%)$ & - & 12 & $1.43 \%$ \\
\hline $\begin{array}{c}\text { H/O previous } \\
\text { blood donation } \\
<3 \text { months }\end{array}$ & 5 & 2 & 8 & - & 9 & - & - & - & $22(3.45 \%)$ & $\begin{array}{c}2 \\
(1.01 \%)\end{array}$ & 24 & $2.87 \%$ \\
\hline Menstruations & - & 9 & - & 4 & - & - & - & - & - & $\begin{array}{c}13 \\
(6.59 \%) \\
\end{array}$ & 13 & $1.57 \%$ \\
\hline $\begin{array}{l}\text { History of blood } \\
\text { transfusion }\end{array}$ & 2 & 1 & 7 & - & 4 & - & 1 & - & $14(2.19 \%)$ & $\begin{array}{c}1 \\
(0.5 \%)\end{array}$ & 15 & $1.79 \%$ \\
\hline Alcohol intake & 2 & - & 5 & - & 6 & - & - & - & $13(2.03 \%)$ & - & 13 & $1.57 \%$ \\
\hline Total & 69 & 138 & 260 & 45 & 176 & 13 & 134 & 1 & $639(100 \%)$ & $\begin{array}{c}197 \\
(100 \%)\end{array}$ & 836 & $100 \%$ \\
\hline
\end{tabular}

Most common cause of permanent deferral chronic uncontrolled hypertension $134(42.4 \%)$, on medication for various reason $50(16.67 \%)$ and Asthma40 (13.20\%). Other causes of permanent deferral were chronic allergic disease, thyroid disease, skin problem like psoriasis, haemoglobinopathy such as thalassaemia minor and diabetes mellitus on insulin. In male and female distribution male deferral was found higher.

Table III : Distribution of permanent deferral by age and sex $(n=316)$

\section{Discussion}

In our study the overall donor deferral rate was about $8.8 \%$ and deferral rate was 2.37 times higher in female compared with male which was similar to that observed by Bahaduret al. ${ }^{5}$ The lowest reported donor deferral was by Talonu ${ }^{6}(4 \%)$, Sundar ${ }^{7}$ $(5.84 \%)$ and high rate was reported by Zou et al ${ }^{8}(12.8 \%)$ and Choudhary et $\mathrm{al}^{9}(16.4 \%)$. However the highest incidence of donor deferral was observed by some studies was between 20$35.6 \%{ }^{10,11}$

\begin{tabular}{|c|c|c|c|c|c|c|c|c|c|c|c|c|}
\hline \multirow[t]{2}{*}{ Causes } & \multicolumn{2}{|c|}{$\begin{array}{c}18-29 \\
\text { yrs }\end{array}$} & \multicolumn{2}{|c|}{$\begin{array}{c}30-39 \\
\text { yrs }\end{array}$} & \multicolumn{2}{|c|}{$\begin{array}{c}40-49 \\
\text { yrs }\end{array}$} & \multicolumn{2}{|c|}{$\begin{array}{c}50-60 \\
\text { yrs }\end{array}$} & \multicolumn{2}{|c|}{ Total } & \multirow{2}{*}{$\begin{array}{l}\text { Grand } \\
\text { Total }\end{array}$} & \multirow[t]{2}{*}{$\%$} \\
\hline & $\mathbf{M}$ & $\mathbf{F}$ & $\mathbf{M}$ & $\mathbf{F}$ & $\mathbf{M}$ & $\mathbf{F}$ & $\mathbf{M}$ & $\mathbf{F}$ & M & $\mathbf{F}$ & & \\
\hline $\begin{array}{c}\text { Chronic } \\
\text { Hypertension }\end{array}$ & 12 & - & 27 & - & 57 & - & 38 & 1 & $134(44.22)$ & - & 134 & $42.4 \%$ \\
\hline Asthma & 11 & 3 & 9 & 2 & 13 & 2 & 7 & & $40(13.20 \%)$ & $8(61.53 \%)$ & 48 & $15.18 \%$ \\
\hline $\begin{array}{c}\text { Chronic allergic } \\
\text { disease }\end{array}$ & 8 & 1 & 7 & 1 & 9 & - & 2 & - & $26(8.58 \%)$ & $2(15.4 \%)$ & 28 & $8.86 \%$ \\
\hline Thyroid disease & 2 & - & 1 & - & - & - & - & - & $3(0.99 \%)$ & - & 3 & $0.98 \%$ \\
\hline Skin disorder & 9 & - & 5 & - & 7 & - & 3 & - & $24(7.92 \%)$ & - & 24 & $7.59 \%$ \\
\hline $\begin{array}{c}\text { Use of } \\
\text { medication due } \\
\text { to various reason }\end{array}$ & 12 & 1 & 11 & 1 & 13 & 1 & 14 & - & $50(16.67 \%)$ & $3(23.07 \%)$ & 53 & $16.77 \%$ \\
\hline $\begin{array}{c}\text { Thalassaemia } \\
\text { minor }\end{array}$ & 1 & - & - & - & - & - & - & - & - & - & 1 & $0.31 \%$ \\
\hline $\begin{array}{c}\text { Diabetes Mellitus } \\
\text { on insulin }\end{array}$ & - & - & 2 & - & 18 & - & 5 & - & $25(8.42 \%)$ & - & 25 & $7.91 \%$ \\
\hline Total & 55 & 5 & 62 & 4 & 117 & 3 & 69 & 1 & $303(100 \%)$ & $13(100 \%)$ & 316 & $100 \%$ \\
\hline
\end{tabular}


In present study most of the deferred donors (55.38\%) were under the age of 40 years which was less similar to Di Lorenzo et al ${ }^{11}$ study.Donor deferral was classified into temporary and permanent .Custer et $\mathrm{al}^{12}$ observed $68.5 \%$ temporary and $31.5 \%$ permanent deferral which was similar to the present study .The temporary deferrals were more than permanent deferrals. The most common cause of temporary donor deferral was anaemia in many studies done by Naveen Agnihotri ${ }^{13}$ (56\%) and Halperin et $\mathrm{al}^{14}$ (46\%) which was comparable with ours. Anaemia was more common in female $(48.73 \%)$ than male donor $(28.16 \%)$ which highlight the prevalence of anaemia in general population among females in a developing country like Bangladesh. Chaudhary ${ }^{9}$ observed the two most common cause of temporary donor deferral were low weight $(32.3 \%)$ and anaemia (18.6\%) which is also comparable with present study. In current study the most common cause of permanent deferral in male was chronic hypertension (42.4\%) which was similar to Sundar $\mathrm{P}^{7}$ and Kulkarni $\mathrm{N}{ }^{15}$ study. Chaudhary ${ }^{9}$ and Ranveet ${ }^{16}$ reported that the most common cause of permanent deferral was history of jaundice which was not similar with our study.

\section{Study limitations}

The present study was conducted in a selected transfusion center of Bangladesh. Generalization from this study, therefore, cannot be made for the whole country. Duration of this study was only 1 (one) year with relatively small sample size. More extensive study will give better insight.

\section{Conclusion}

In this study, reasons for deferral of volunteer blood donors were studied and found the deferral rate was low and most of the deferred donors were young adult. Temporary deferred were higher than permanent deferred donor. The most common reasons for temporary deferral were anemia, underweight and hypotension. Permanent deferral causes were chronic uncontrolled hypertension, donors on medication for various reason and asthma. Since most of the deferrals were temporary deferrals, we should give a clear message for the reason for deferral and duration of deferral so that they return for donation in the future on correction of the cause of deferral at appropriate duration.

\section{References}

1. Unnikrishnan B, Rao P, Kumar N, Ganti S, Prasad R et al. Profile of blood donors and reasons for deferral in coastal South India. Australasian Medical Journal. 2011; 4(7):379385.

2. World Health Organization. Blood Donor Selection: Guidelines on Assessing Donor Suitability for Blood Donation. Geneva: World Health Organization; 2012:16-23.)

3. Newman B. Blood donor suitability and allogenic whole blood donation. Transfus Med Rev. 2001;15:234-44.

4. Brecher ME. 15th Edition. Bethedsa: AABB press; 2005. AABB Technical Manual; p. 101.

5. Bahadur S, Jain S, Goel RK, Pahuja S, Jain M. Analysis of blood donor deferral characteristics in Delhi, India. Southeast Asian J Trop Med Public Health. 2009;40(5):1087-91.

6. Talonu T. Causes of volunteer blood donor rejection in Papua New Guinea. P N G Med J. 1983;26:195-7.

7. Sundar $P$, Sangeetha SK, Seema DM, Marimuthu P, Shivanna N. Pre-donation deferral of blood donors in South Indian set-up: An analysis. Asian J Transfus Sci.2010 July; 4(2):112-115.

8. Zou S, Musavi F, Notari EP, Rios JA, Trouern-Trend J, Fang CT. Donor deferral and resulting donor loss at the American Red Cross Blood Services, 2001 through 2006. Transfusion. 2008;48(12):2484-6.

9. Chaudhary RK, Gupta D, Gupta RK. Analysis of donor-deferral pattern in a voluntary blood donor population. Transfus Med. 1995;5:209-12.

10. Charles KS, Hughes P, Gadd R, Bodkyn CJ, Rodriquez M. Evaluation of blood donor deferral causes in the Trinidad and Tobago Naional Blood Transfusion Service. Transfusion Med. 2010;20(1):11-14.

11. Di Lorenzo Oliveira C, Loureiro F, de Bastos MR, Proietti FA, Carneiro-Proietti AB. Blod donor deferral in Minas Gerais State, Brazil: blood centers as sentinels of urban population health. Transfusion. 2009;49(5):851-7.

12. Custer B, Johnson ES, Sullivan SD, Hazlet TK, Ramsey SD, Hirschler NV, Murphy EL, Busch MP. Quantifying losses to the donated blood supply due to donor deferral and miscollection. Transfusion. 2004;44(10):1417-26.

13. Naveen Agnihotri. Whole blood donor deferral analysis at a center in Western India. Asian J Transfus Sci.2010; 4(2):116-122

14. Halperin D, Baetens J, Newman B. The effect of short term temporary deferral on future blood donation. Transfusion. 1998;38:181-3.

15. Kulkarni N. Analysis of donor deferral in Blood Donors .Journal of Evolution of Medical and Dental Sciences 2012;1(6):1076-83

16. Ranveet Kaur, Sabita Basu, Neelam Marwaha . A reappraisal of underlying causes in donor deferral. Ann NatlAcad Med Sci. 2002; 38:93-9 